\title{
NON-AGENDA
}

With the view of causing an increase to take place in the mass of national wealth, or with a view to increase of the means either of subsistence or enjoyment, without some special reason, the general rule is, that nothing ought to be done or attempted by government. The motto, or watchword of government, on these occasions, ought to be - Be quiet...Whatever measures, therefore, cannot be justified as exceptions to that rule, may be considered as non-agenda on the part of government.

— Jeremy Bentham (c.1801)

\section{Iraq: The Neocon Strategy}

\section{Ron Huisken}

As is well known, in the months after 11 September 2001, the United States developed its strategy for a 'global war on terror'. This strategy, the Bush Doctrine, signaled a strong preparedness to act unilaterally and pre-emptively and identified an 'axis of evil' - Iraq, Iran and North Korea - as its principal target. These states were singled out because they were deemed to be most likely to equip terrorist groups with weapons of mass destruction (WMD). What is less well known is that a number of key figures in the administration, though perhaps not the President himself initially, were already wedded to a novel strategy to focus US foreign and security policy settings. This 'grand strategy', crafted by neoconservative officials in the Pentagon in 1989-92 (and hereafter called the Pentagon strategy) broadly contended that unipolarity provided a superior basis for a stable international order and that, as the unipolar power, the United States should both declare its intention to take charge, and ensure that its preeminence was not challenged. These sentiments represented a quite radical departure from the approach the US had preferred for more than a century.

The contention here is that the Pentagon strategy is essential to understanding the thrust of the Bush administration's foreign and security policy settings both before and since September 11. In particular, the interplay between the Pentagon strategy and the Bush doctrine on terror is essential to understanding the administration's fierce determination to secure regime change in Iraq and, in critical ways, the manner in which this objective was pursued. In other words, this neocon strategy played an essential role in shaping what has become perhaps the

Ron Huisken is a Senior Fellow in the Strategic and Defence Studies Centre, Research School of Pacific and Asian Studies, at the Australian National University. 
most damaging venture in US history, a venture that will make the geopolitics of the $21^{\text {st }}$ century very different from what seemed possible and likely in 2000. Our starting point is the rather unusual genesis of the neocon strategy.

\section{Sources of Neoconservative Thinking}

It is important to note, first of all, that the central thesis of the Pentagon strategy was not the literal adoption of a particular strand of obscure academic thinking. It would seem that the foundations for the strategy were built up rather pragmatically - 'discovered' as the then Secretary of Defence, Richard Cheney, put it - in response to the challenge of defending the Pentagon's budget from the pressures for a post Cold War peace dividend. In an informal conversation with the author, a former Pentagon official involved in drafting the strategy, said that a major consideration was that the United States had gone through some major scares during the Cold War and should at all costs avoid the emergence of another peer competitor. Given the opportunity to build a new order, the first requirement was to avoid getting back into a glass jar with another scorpion (the classic depiction of the United States and the Soviet Union in circumstances of mutual assured destruction). The obvious precursor to a global rival was the emergence of a regional hegemon where the resources of the hegemon and its immediate region provided the strategic muscle to challenge the United States globally. This, too, had to be prevented. Regions like Africa and Latin America could be ruled out with reasonable confidence as a springboard for global rivalry with the United States. But Europe, the Middle East and East Asia were another matter.

It should also be noted that it was entirely appropriate for the United States to re-think its defence posture. By the time the Soviet Union imploded, the United States had spent about US\$20 trillion developing nuclear and conventional forces and a global network of allies, bases and facilities to deter direct aggression by the Soviet Union, and to prevent it from making strategic gains in regions important to the United States. Moreover, notwithstanding the bureaucratic imperatives that contributed to the strategy devised in the Pentagon, the thrust of their thinking was not without merit. With the end of the Cold War, America's effective power had risen dramatically to levels without precedent in modern history. What was America to do? Use that power, try to share it, or break it up and re-join the ranks of the other bigger states? The Pentagon's answer was by no means indefensible, particularly if one recalls the anxieties in the early 1990s in Europe and East Asia generated by Washington's planned diminution of its forward military presence.

The neocon prescription differed significantly from that of the Realists, the mainstream school of thought about these matters. Realists contended that America's propensity toward idealism and messianism had to be held in check by a rigorous focus on 'national interests'. The policy prescription from this school was to guard against the risk that winning the Cold War would encourage the view that America, the state that was the exception to all other hegemonic powers the world had ever experienced, was now really free to reshape the world to its advantage, and that doing so, would be recognised by all (or nearly all) as to their 
benefit as well. Realists favoured the discipline of recognising the limits of American power and confining the nation's foreign policy ambitions to the protection and advancement of rigorously defined national interests (Kagan, 1995). Stanley Hoffman (1990/91) was by no means alone among prominent academics in suggesting that the end of the Cold War amounted to a discontinuity in international affairs, and that the best way forward for the United States was consciously to redistribute some of its residual power and conduct an experiment in the 'polycentric steering' of global affairs (Hoffman, 1990).

President George H. Bush, though probably the most understated of America's postwar leaders, accepted that America had to lead. While this President contended that there was no one else that had the capacity or the global acceptance to do so, his preference was to lead quietly and cheaply. And while he coined the phrase, a 'new world order', he also famously observed that he had little stomach for the 'vision thing', and US policies remained focused on consolidating an orderly transition out of the Cold War, particularly in Europe.

The authors of the Pentagon strategy, however, drew inspiration from Bush's predecessor, Ronald Reagan. Reagan is characterised as having been instinctively opposed to the caution and limits of the Realist thesis. He is seen by conservative admirers as having had 'unwavering confidence in the rightness of the American cause, in the appropriateness of using power in its service' and of investing the struggle with the Soviet Union with the attributes of a crusade, of a struggle between good and evil (Kagan, 1995:19). These admirers consider that in doing so, that is, aligning American foreign policy with the ideals of the American people, Reagan recorded spectacular accomplishments, hastening the end of the Cold War and vastly increasing America's influence worldwide in both strategic and ideological terms. This assessment of the Reagan presidency underpins a thesis closely identified with the neoconservatives on guidelines for America's foreign and security posture. This thesis asserts that, whatever else it did, America's rise to primacy suppressed the instability and conflict that was endemic to both Europe and East Asia prior to 1945. It seemed to follow that, if the United States vacated this position or sought to share it with others, the probable outcome would be a revival of the accident-prone balance-of-power system that existed through the first decades of the $20^{\text {th }}$ century, a prospect made more alarming by the development of nuclear weapons since that time (Kagan, 1995:25).

The thought that the US could replace the balance of power mechanism (and the implicit contention that there was no sensible alternative to US hegemony) developed into a key intellectual construct in the Pentagon strategy. The United States, in other words, had to remain sufficiently strong to go on making any resort to collective leadership, and the attendant risks of instability and conflict, not only unnecessary but also unfeasible. This view of history also brought with it the primacy of military power.

A conservative American scholar, Andrew J. Bacevich (2005), has argued in a recent book that a much deeper phenomenon might be at work here. Bacevich contends that, particularly since the end of the Cold War, no part of the American system of governance — political leaders, the media, and the general public — has 
seriously contested the valuing of military power for its own sake or considered whether global military superiority might be at odds with American principles. Moreover, this acceptance developed alongside a reinforcing transformation in the image of war, away from mass armies lavishly equipped with the industrial implements of war, to a more aesthetically respectable abstract activity conducted at a considerable distance from the enemy, but still with great precision and effectiveness, and entailing an almost negligible risk of discouraging numbers of US casualties. Unsurprisingly, in Bacevich's view, these developments manifest themselves in an increased propensity to use force, and indeed to positioning the use of force in the spectrum of diplomatic tools (coercive diplomacy) rather than, as in the past, beyond that spectrum as evidence that diplomacy had failed.

Wherever President George W. Bush (Bush Jnr) may have stood at the beginning of his term with respect to the Pentagon's grand strategy, the priority he attached to the Pentagon was never in doubt. Barely three weeks after his inauguration in January 2001, he signalled that he had authorised Secretary of Defense Donald Rumsfeld to proceed forcefully to transform the US armed forces to take full advantage of the technologies often described as the Revolution in Military Affairs, adding that 'the best way to keep the peace is to redefine war on our terms'.

\section{A Security Strategy for a World Without the Soviet Union}

After the Berlin Wall came down in November 1989, senior officials in the George H. Bush (Bush Snr) Administration confronted the most novel of challenges. For forty years, the Soviet Union had essentially answered the questions of what the United States should focus its foreign and security policies on, and on how strong the US armed forces needed to be. Now, advancing the Soviet Union as the answer to these questions no longer worked. Moreover, the administration encountered a clamour of Congressional and public expectations for both a substantial 'peace dividend' (of the order of 50 percent in terms of military personnel and the defence budget) and significant relief from the international obligations and responsibilities that America had assumed during the Cold War. The Administration's response combined high strategy — trying to discern the essential contours of the post-Cold War world and devising a posture that would ensure the United States prospered in that world - and low-strategy coming up with arguments that would deflect rising public and Congressional sentiments for a quick and substantial 'peace dividend'.

As Secretary of Defense, Dick Cheney had two teams working these questions, one led by Colin Powell, who had been appointed Chairman of the Joint Chiefs of Staff in October 1989, and the other by his Under Secretary for Policy, Paul Wolfowitz. Powell and Wolfowitz were not soul mates by any means, but they agreed that comfortable US superiority in military power was much to be preferred to other possible yardsticks for 'how much is enough'. Cheney saw the calls for a major peace dividend as giving up options long before it was clear that it was safe and smart to do so, particularly in light of the consequences of US 
demobilisations following the First World War — being unable to galvanise Europe into an earlier response to Nazism - and the Second World War - when, five years after this conflict ended, a very modest power like North Korea almost succeeded in driving the United States off the Korean peninsula.

\section{A Modest First Cut}

Cheney selected points from both teams to prepare a package to recommend to the President. This initial effort was fairly routine, citing the inescapable role of global leadership; the desirability of hedging against a revival of Soviet power; the challenge of containing the spread of WMD; and other regional dangers like dictators and terrorism; to counter the pressures for slashing the Pentagon budget. The President opted to get on the front foot politically and offer a peace dividend, but to use this concession to hold the draw down well short of the 50 percent being talked about, whether in terms of personnel or dollars. Bush (Snr) proposed that active duty military personnel and military expenditure in real terms would be cut by 25 percent and 30 percent respectively over the period 1990-1995. Ironically, the President articulated this position in a speech in Aspen, Colorado on 2 August 1990, the night that Iraq invaded Kuwait. As quoted by Lewis Libby (1990/91), on that occasion the President said:

Our new strategy must provide the framework to guide our deliberate reductions to no more than the forces we need to guard our enduring interests - the forces to exercise forward presence in key areas, to respond effectively to crises (and) to retain the national capacity to rebuild our forces should this be needed.

This relatively soft position on the armed forces (especially for a Republican president) was reiterated the following year when Bush released the National Security Strategy of the United States, in August 1991. These are the most authoritative American statements on national security and are typically crafted by officials in the White House and the National Security Council (headed at the time by Brent Scowcroft). As quoted by Lewis Libby (1990/91), the National Security Strategy of August 1991 said:

If the end of the Cold War lives up to its promise and liberates US policy from many of its earlier concerns, we should be able to concentrate more on enhancing security - in the developing world, particularly through means that are more political, social and economic rather than military; and

In the face of competing fiscal demands and a changing but still dangerous world, we have developed a new defense strategy that provides the conceptual framework for our future forces. This new strategy will guide our deliberate reductions to no more than the forces 
we need to defend our interests and meet our global responsibilities. (emphasis added)

The italicised words in particular, which echoed those the President used a year earlier on the eve of the first Gulf crisis, suggested a mindset on military forces, just enough, that the policy elite in the Pentagon was beginning to see as ignorant both of the lessons of history and of the dimensions of the opportunity that history had presented to the United States.

The task of liberating Kuwait naturally defused the immediate political pressure for a peace dividend. It would seem, however, that it was recognised as temporary and that pressures for a markedly smaller military capability would resurface in due course. If the Administration was to resist these pressures, it would need to support its case with a more profound and coherent strategy. This judgment was reinforced dramatically by the break-up of the Soviet Union in December 1991. To this point, hedging against a revival of Soviet power and political will had underpinned the case for caution and moderation in downsizing the US military. By that time, too, Iraq had been evicted from Kuwait, its conventional forces had been significantly diminished, and the United Nations was busy erasing its WMD and ballistic missile capabilities. As anticipated, Congressional calls for a large peace dividend resurfaced with new intensity.

\section{The Strategy Expands}

The vehicle for devising a more considered national strategy to support sustaining a significant military effort turned out to be the Defence Planning Guidance (DPG). This is a classified internal Pentagon document prepared every two years to assist the many component agencies in determining the capabilities expected of them to meet defence policy objectives and the funding they consider necessary to achieve those capabilities.

Cheney assigned the task of drafting the DPG to Paul Wolfowitz, who in turn delegated it to a senior deputy, Lewis 'Scooter' Libby. Libby tasked another Wolfowitz staffer, Zalmay Khalilzad to conduct the necessary consultations within the Pentagon, hold meetings on themes, concepts and so on, and to do the initial drafting. Libby went on to become Vice President Cheney's Chief of Staff over the years 2001-05, while Khalilzad became the US ambassador, first to Afghanistan in 2004, and then Iraq in 2005.

Khalilzad's draft followed the new convention that, in the absence of a global challenge and an associated 'central front', the focus of attention in the future, and indeed the highest level of strategic analysis, would have to be the stability of particular regions important to the United States. The draft called for the United States to be the dominant outside power in the Middle East and Persian Gulf regions to protect access to oil. In Europe and Asia, the United States would seek to prevent any of the resident major powers from dominating the region and perhaps using the consolidated resources of the region as a springboard to global power status. On WMD, the draft noted that that 'the United States could be faced 
with the question of whether to take military steps to prevent the development or use of weapons of mass destruction', a rather clear indication that pre-emption could emerge as the preferred or necessary option.

The draft went a crucial step further to suggest that the United States should actively discourage the emergence of potentially competitive powers, and pointed to several policy settings that would contribute to this objective. Specifically:

First, the United States must show the leadership necessary to establish and protect a new order that holds the promise of convincing potential competitors that they need not aspire to a greater role or pursue a more aggressive posture to protect their legitimate interests. Second, in the non-defense areas, we must account sufficiently for the interests of the advanced industrial nations to discourage them from challenging our leadership or seeking to overturn the established political and economic order. Finally, we must maintain the mechanisms for deterring potential competitors from even aspiring to a larger regional or global role. An effective reconstitution capability is important here, since it implies that a potential rival could not hope to quickly or easily gain a predominant military position in the world. ${ }^{1}$

These thoughts went to the heart of the brief. They mandated a militarily dominant United States capable of acting independently when collective action could not be orchestrated and visibly positioned to increase its military power faster than any potential competitor. Cheney considered these strands of thinking to be a promising step toward a strategy that would be politically viable and would protect US military superiority.

\section{Controversy}

There was a snag, however. Although this strategy committed the United States to a very demanding and costly international role into the indefinite future, no other groups in the foreign and security policy community in Washington had yet even been exposed to it, let alone persuaded of its merits. In other words, there had been no whole-of-government assessment and review. Indeed, as we have already seen, it ran counter to sentiments elsewhere in the Administration, particularly the White House, and may even have been intended to contest these sentiments. So when a copy of the document was leaked to the New York Times in March 1992, its thesis was savaged from all sides. A focus of the furore was the implication that the major powers that the United States would seek to keep down included close allies like Japan and Germany along with, presumably, China and Russia. President Bush (Snr) asked not to be held accountable for a document that he had never seen. Even Wolfowitz claimed that it was a working draft that had been circulated in the Pentagon for wider input, and that he had not yet read what his

1 Quoted in Patrick E. Tyler, US Strategy Plan Calls for Ensuring No Rivals Develop: A One Superpower World, New York Times, 8 March 1992. 
staff had concocted (not entirely unreasonable to anyone who has served in a large bureaucracy, but still a stretch).

While the President and Wolfowitz publicly distanced themselves from the document, Secretary Cheney privately praised the 'discovery' of a 'new rationale' for America's role in the world (Mann, 2004:211). Still, in view of the criticism and the President's discomfit with the document, the impression had to be conveyed that this was not the policy of the United States (which, indeed, it was not) and that something else would be crafted to replace it. Cheney signalled that the document would be rewritten. A new draft, appropriately softer in tone and giving new prominence to the importance of allies and the United Nations, was also 'leaked' (in May 1992) without reviving the controversy. After this, as the Presidential election campaign of 1992 intensified, the issue seemed to disappear.

\section{The Strategy Makes its Public Debut}

The saga of the Defense Planning Guidance had one more chapter. We now know that Cheney assigned the rewriting of the leaked draft to Lewis 'Scooter' Libby, Khalilzad's immediate superior (Mann 2004:211). We also know that Libby favoured a further twist of the Khalilzad draft: not only should US military superiority be so stark and overwhelming that no other state would even consider setting out on the long road to challenge it, that superiority should also be extant rather than dependant on a reconstitution capability. In this way, unipolarity, at least in the military dimension, would remain a permanent feature of the international landscape.

The final draft of the Defence Planning Guidance might have remained invisible. Journalists learned, however, that in the last days of the administration (that is, in January 1993) Cheney took the front half of the new DPG, which set out the overall strategy, and issued it in his name as a public document: Defense Strategy for the 1990s: The Regional Defense Strategy. It is instructive, therefore, to take a closer look at this statement.

Cheney's defence strategy was an eminently marketable product, presenting a relatively optimistic view of the security outlook and highlighting allies (frequently) as a critical strategic asset for the United States. America's network of alliances constituted a 'zone of peace' and a 'framework for security not through competitive rivalry in arms, but through cooperative approaches and collective security institutions'(Cheney, 1993:2)

Several interesting themes permeated the document. One was the notion that the end of the Cold War had given the United States greater 'strategic depth'. This outcome, which took as given the fact that the United States was militarily dominant in every region that mattered, resulted from two factors. First, that the Soviet Union was no longer there to boost the military potential of regional actors threatening US interests. Second, absent the pervasive ideological contest with the Soviet Union and the Cold War concern that even peripheral Soviet gains could begin to tip the central balance, the United States no longer had to spread its resources to cover every front. It now had greater choice about where it should 
focus its energy. A third factor might be regarded as implicit in these two but worth drawing out. The demise of the Soviet Union not only greatly enhanced America's relative power, it also made it much safer for the United States to exercise that power. During the Cold War, any clash of US and Soviet armed forces carried an irreducible risk of escalation to strategic nuclear war. This inhibiting risk was now gone. Cheney's document stressed that this relatively luxurious position had been won at great cost and should therefore not be 'squandered'.

A second theme Cheney stressed was that allied support was most effectively assured if it was clear that the United States had the ability, and the will, to win by itself if necessary. History, the document plausibly argued, 'suggests that effective multilateral action is most likely to come about in response to US leadership, not as an alternative to it' (Cheney, 1993:4). Preserving the ability to act independently was essential insurance, and responded to the lessons of history. Later, and with considerable prescience, the document addresses possible domestic impediments to the role it recommended the United States play. Specifically, Cheney's document argued that the security challenges of the future would not be the major, global, relatively black and white contests that the American public could be relied upon to support. On the contrary, US interests in regional conflicts 'may seem less apparent' and US involvement rather more optional. To counter the risk that future administrations may find it difficult to generate or sustain public support for military ventures in distant places, the United States needed the capacity to respond decisively to regional crises, 'to win quickly and with minimum casualties'.

The document did not repeat the proposal that the United States should actively discourage the emergence of rival powers, but it came close (p. 4):

It is not in our interests or those of the other democracies to return to earlier periods in which multiple military powers balanced against one another in what passed for security structures, while regional, or even global peace hung in the balance; and

Our fundamental belief in democracy and human rights gives other nations confidence that our significant military power threatens no one's aspirations for peaceful democratic progress

Other language in the document betrayed a deep appreciation of the political options that flowed from America's emergence from the Cold War as a military colossus. The notion of shaping security environments is a very old one. It refers to activities, including military activities, designed to discourage and deter developments deemed injurious to the national interest. Cheney's document, however, goes a significant step further to suggest, throughout, that the US objective should be to preclude (that is, make impossible) regional threats and challenges, or hostile non-democratic powers from dominating regions of importance to the United States. This posture, the document states, 'is not simply within our means: it is critical to our future security’. Many analysts would see in 
this observation evidence of the propensity in hegemonic states toward strategic over-reach, that is, toward the adoption of postures that almost ensure the eventual exhaustion of the capacity or the collapse of the political will needed to sustain them.

\section{Post-Clinton Revival}

The Pentagon strategy vanished during Clinton's Presidency. It was revived in 2000 during the Bush-Gore election campaign by the conservative think tank Project for a New American Century, but there was no trace of it in George Bush's election platform. Importantly, however, when the 1989-1992 Pentagon team reassembled under President George W. Bush in 2001, they set out to put its thinking into practice even before the events of 11 September 2001. Notably, this was done through disabusing Russia of any claim to share the stage with the United States (casting off the ABM treaty and the practice of coordinated reductions in strategic nuclear forces), and through the Quadrennial Defense Review which foreshadowed the intent to shape regional security developments more intensely and on a much broader scale than in the past.

Eventually, in June 2002, the President declared the Pentagon strategy to be the policy of the United States, using the starkest formulations of its key premises. Speaking at the West Point military academy on 1 June 2002 (Bush, 2002), President Bush said:

As we defend the peace, we also have an historic opportunity to preserve the peace. We have our best chance since the rise of the nation-state in the $17^{\text {th }}$ century to build a world where the great powers compete in peace instead of prepare for war. The history of the last century, in particular, was dominated by a series of destructive national rivalries that left battlefields and graveyards across the earth. Germany fought France, the axis fought the allies, and then the East fought the West, in proxy wars and tense standoffs, against a backdrop of nuclear Armageddon.

Competition between great nations is inevitable, but armed conflict is not. More and more, civilised nations find themselves on the same side - united by common dangers of terrorist violence and chaos. American has, and intends to keep, military strengths beyond challenge, thereby making the destabilizing arms races of other eras pointless, and limiting rivalries to trade and other pursuits of peace.

\section{Conclusion}

Iraq has been disastrous for the United States and for the world order that it underpinned. The preparatory phase in 2002 became a prolonged diplomatic debacle, shattering that most extraordinary coalition of the willing that had 
gathered around Washington after the attacks of September 11. And the invasion strategy was so deeply flawed that nearly four years later even the most modest characterisations of success look increasingly elusive. This outcome came about in significant part because US leaders had two strategic agendas and, in maneuvering between them, lost focus and discipline.

Iraq became the issue that wobbled confusingly between the two security strategies in play in Washington in 2001-2003. Regime change in Iraq had much more to do with the Pentagon strategy than with the 'war on terror'. It was perceived as a move that would look back and erase what was seen as a black mark on America's curriculum vitae as a power that finished what it started. And, looking forward, it was seen as providing an enduring illustration of the fact that the United States had both the capacity, and the will, to impose its vision for international order. More specifically, the prescriptions that flowed from the Pentagon strategy directly and indirectly shaped several of the crucial errors of judgement made in respect of using force to bring about regime change in Iraq and replace it with a democratic government.

First, although the case for action against Iraq was broad, it lacked a concrete link to the attacks on 11 September 2001 and to the political window of opportunity for decisive action that the attacks had opened. Regime change in Iraq therefore had to be positioned as a priority in the war on terror. Expectations and hopes that proof would emerge of Iraqi involvement in the attacks or of some form of strategic association with al Qaeda had to be abandoned. The administration then settled on WMD as the remaining rationale that was sufficiently focused and compelling to at least bring the Congress and the public along. Crucially, however, this rationale appeared to be a fallback, a means to an end, rather than a concern able in itself to support the use of force to secure a regime change in Iraq. As we know, confirming this rationale proved surprisingly difficult, and the administration found itself slipping into the manipulation and hyping of the intelligence at its disposal only to have the most obvious explanation for the difficulty confirmed after the invasion: Iraq had not had WMD for some time, and was not poised to re-acquire them.

Second, Iraq was the vehicle chosen to herald the Pentagon's 'grand strategy'. Most importantly, this objective put a premium on dislodging Saddam Hussein with a spectacularly lean combat force. The intent was to send a graphic signal that the United States could perform even large-scale regional security tasks using a fraction of the forces available to it and without lowering its guard in other areas. This ambition led to discounting the contrary consideration that an overwhelming military presence might be prudent for the purposes of occupation and stabilisation. The Bush Administration's stoic refusal to revisit this judgement saw the United States progressively lose control of the agenda within Iraq (and, later, cost the administration control of both houses of Congress).

Third, but related to the preceding point, the window of opportunity to deal with Iraq was deemed to be so precious that the administration elected to minimise the risk that thinking through or planning for possible worst case developments would reach the public, or the Congress, and soften support for regime change. 
Almost literally, that meant not doing any such preparatory thinking about, and planning for, the period after the Iraqi armed forces had been defeated and to sidelining such work as had been done. George Packer (2006) has provided a sobering account of this extraordinary process. The result was that, after taking Baghdad, US commanders in Iraq had no guidance, and a confused chain of command back to Washington. They stood aside for what seemed like an eternity, dissipating the momentum of their military success, leaving Iraqis wondering who, if anyone, had replaced Saddam Hussein, thus giving those disposed to resist the occupation through insurgent operations a whiff of hope.

Finally, as the awful consequences of these judgements began to loom, getting inside and destroying the emergent insurgency became a matter of the utmost importance, a matter of doing whatever it takes. This contributed rather directly, in the author's view, to the graphic excesses at Abu Ghraib. The Abu Ghraib saga, along with Camp Delta, the legal gymnastics over 'enemy combatants' and the Geneva Conventions, and the inevitable relentless stream of accidents and miscalculations involving Iraqi civilians when a top-end combat force is both stretched thin and tasked to conduct counter-insurgency operations, saw the United States lose all the moral high ground.

The Pentagon strategy started modestly, a bureaucratic counter-attack on the post-Cold War movement for a peace dividend, but blossomed into a dramatic declaration of hegemony that cut across the image that America had been at pains to project for more than a century. It was constructed wholly within the Pentagon, receiving neither whole-of-government review nor electoral endorsement. One apparent consequence of this pedigree, apart from the starring role assigned to military power, is that scant attention was paid to the crucial dimension of the statesmanship and diplomacy required to sell such a strategy to the rest of the world, particularly the other major powers. That opportunity has been decisively lost.

The invasion of Iraq in March 2003 amounted to nothing less than a virtual breakdown in America's system of governance. This system of governance, dominated by the checks and balances on executive power, and which had endured so many trials was, in the final analysis, the source of America's most valuable asset: its singular capacity to be ominously powerful yet not be regarded as an ominous power. It will be some time before an American President can again say, as did George Bush's father, that the 'world trusts us to do what is right'.

The tragedy in Iraq has also been a painful lesson in alliance management for Australia, a lesson that we should not have really had to re-learn. After 60 years of close friendship, Australia has unrivalled access in Washington. This applies to the political, military and intelligence circles. There is not much that transpired within government in Washington in 2002 and 2003 that would have entirely escaped our attention. Yet there is no shred of evidence that Canberra became concerned at any point that the Bush administration was not thinking coherently about Iraq. Canberra elected simply to be a loyal ally, rather than a close friend with shared values and interests able and willing to speak frankly and deliver hard advice. All we did was to belatedly, but very perceptively, limit our own exposure 
through essentially declining to commit the ADF to the so-called Phase IV stabilisation and reconstruction - of Operation Iraqi Freedom. And we managed to sustain that position until early 2005. Being a more demanding ally may not have made a difference, but in apparently not even trying we served neither our own nor American interests.

\section{References}

Kagan, R. (1995), ‘A retreat from Power?’, Commentary, July, 100(1):19-25.

Hoffman, S. (1990/91), 'America's Heritage, in America's Role in a Changing World', Part 1, Adelphi Papers No. 256:3-22.

Hoffman, S. (1990), A New World and its Troubles, Foreign Affairs Fall:115-122.

Bacevich, A.J. (2005), The New American Militarism: How Americans are seduced by war, Oxford University Press. London.

Libby, L (1990/91), 'Remarks on Shaping US Defence Strategy: Persistent Challenges and Enduring Strengths', in 'America's Role in A Changing World', Part 2, Adelphi Papers No. 257.

Mann, J. (2004), The Rise of the Vulcans: The History of Bush's War Cabinet, Penguin Books, London.

Cheney, R. (1993), 'Defense Strategy for the 1990s: The Regional Defence Strategy', Department of Defense, Washington DC.

Bush, G. W. (2002), ‘President’s Graduation Speech’, West Point Military Academy, New York.

Packer, G. (2006), The Assassins Gate, Faber \& Faber, London.

This article is adapted from the author's monograph, Iraq: Why a strategic blunder looked so attractive, Strategic \& Defence Studies Centre, ANU, Working Paper No.369, July 2006. The author is grateful for the comments on a draft of this article provided by two anonymous referees. 